\title{
Research on the Influence of the Intellectual Property Rights Protection on the Strategy of Multinational Enterprises (MNEs) and Foreign Direct Investment (FDI)
}

\author{
Wenjia Zhang ${ }^{1, *}$
}

\author{
${ }^{1}$ University of Glasgow, Glasgow G1 1RU, UK \\ *Corresponding author. Email: ll852073789@163.com
}

\begin{abstract}
Economic globalization has influenced the global in wide range. At the same time, more and more attention is paid to the protection of intellectual property rights. In that case, this paper discussed how intellectual property rights influence the economic business in different types of countries. This paper used the quality method to analysis. Through analysis, the author considered that the developing economies will have more complete system of Intellectual Property Rights Protection with the economic development, which will raise the proportion of FDI. The countries with weaker level of Intellectual Property Rights Protection need to choose suitable intellectual property protection method which can match their own level of technology.
\end{abstract}

Keywords: intellectual property rights, MNEs, FDI

\section{INTRODUCTION}

Economic globalization is the main feature of the development of modern world economy, and one of the first manifestations of economic globalization is the globalization of capital. Increasing the scale of crossborder investment is the result of capital profit-making and the globalization of capital means diminishing globalization. Developed countries and transnational corporations often use their monopoly position and competitive advantage to seek profits and economic resources of developing countries. As an important institutional arrangement to encourage social innovation, the intellectual property system is one of the key elements of discretion of multinational enterprises in the process of deciding investment. Intellectual property protection, as an institutional arrangement, plays different roles in different levels of economic development. It affects not only the ability of innovate for a country, but also the flows of FDI. At first, the background of this topic has been showed. Secondly, the method of how intellectual property protection system affects the strategic choices of multinational enterprises has been discussed. Followed by the two types of FDI and their respective roles in countries at different levels of development have been described. Finally, a conclusion and the future work will be provided.

\section{THE BACKGROUND}

Intellectual property has become an important part of enterprise competitiveness and an important symbol of national soft power. The digital revolution and technological breakthroughs in recent years have made the intellectual property as a frontier interests of economy and social as well as the politics (Ezell and Cory, 2019). Intellectual property protection should be based on the economic conditions and innovation capacity of a country (Hargreaves, 2011). Besides, intellectual property rights are often non-rivalrous which means the marginal cost is small if there have another agency use it (Ghosh, 2008). Comprehensive intellectual property legislation and effective enforcement level can help to reduce the risk of infringement and encourage enterprises to make longterm investment in intangible assets in order to enhance their own innovation ability and market competitiveness (SÁIZ and CASTRO, 2017).

\section{THE THEORY OF SYSTEM ESCAPE AND THE THEORY OF SYSTEM PROMOTION}

The influence of the intellectual property protection system of the host country on the overseas expansion of enterprises is mainly divided into the theory of system escape and the theory of system promotion. Institutional escape theory holds that the institutional deficiencies and market inefficiencies faced by enterprises of emerging economies at their own country has led many local companies to use overseas expansion as a strategic 
option to acquire strategic resources and avoid domestic institutional deficiencies (Luo and Tung, 2007). Besides, the institutional flaws in home countries stimulate companies to make OFDI. Due to the fragility of the home country system, that is, the various dimensions of the system are not coordinated in parallel, thus creating internal contradictions in the process of system development, which encourages enterprises in emerging economies to flee the home country system by way of foreign investment (Witt and Lewin, 2007).

Contrary to the above theory, scholars who support the theory of institutional promotion believe that the host country system provides impetus and support for the internationalization of enterprises (Hitt et al., 2004). The higher the level of intellectual property protection in the home country, the stronger the awareness of intellectual property protection of local enterprises, which helps to reduce the intellectual property disputes in the international operation of enterprises, so that enterprises have more confidence to make international decisions. Furthermore, the better the intellectual property protection system moves towards a market economy, the better it helps to reduce government intervention, promote contract enforcement, reduce transaction costs, increase market effectiveness, and thus promote the expansion of enterprises of emerging economies into global markets. Furthermore, in addition to enterprise resources and industry elements, institutional forces will also significantly affect the export behavior of enterprises. The study found that the better the institutional environment in which the enterprises are located, the higher the export tendency of the enterprises.

\section{THE INFLUENCE OF INTELLECTUAL PROPERTY PROTECTION ON THE INVESTMENT CHOICE}

Intellectual property protection can affect the choice of investment of multinational enterprises in overseas market by influencing ownership advantage, location advantage and internalization advantage. The ownership advantage of transnational corporations is affected by the improvement of the level of intellectual property protection by the market expansion effect and the effect of market power. If the host country enterprises have a strong ability of imitation, the increase in intellectual property protection will increase the ownership advantage and thus increase the way in which multinational enterprises invest in overseas markets. While, if the host country enterprises have weaker imitation capacity, the effect will be opposite, and the increase in protection will reduce the way of multinational enterprises invest in overseas markets. Secondly, strengthening intellectual property protection reinforces location advantage, which encourages Multinationals to move away from exports and towards technology licensing and foreign direct investment (FDI)(Smith, 2001). In addition, if intellectual property protection is strong enough, it will reduce the internalization of multinational enterprises, in which case they are encouraged to choose technology licensing in a way that would replace the original export and direct foreign direct investment (FDI) with host country enterprises. Besides, because internationalization is highly dependent on the financial resources of enterprises in the factor market, the better the ability of the enterprise to obtain capital from its home country, the stronger the enterprise's ability to survive, and the more conducive to promoting the internationalization process (Hoskisson et al., 2013). The higher the level of intellectual property protection in the region in which the enterprise is located, the easier it is for enterprises to obtain capital and credit from external investors, thus promoting the internationalization process of enterprises (Liu and Jiang, 2016). When the threat of imitation is high in export markets, internalization advantages are consolidated by raising the level of intellectual property protection, and multinational enterprises are choosing export and FDI as alternatives to the technology licensing model. The level of patent protection in the host country will have an impact on the choice of export, FDI and technology licensing by multinational enterprises at least through the following channels: on the one hand, if the patent protection rights of the host country is in a high level, the risk of imitation, uncertainty factors and the transaction cost of technology contracts will be declined, which in this way encourage multinationals to choose the technology licensing rather than direct exports. On the other hand, if the patent protection of host country is in a low level, enterprises will make a different choice. This is because the weaker the protection of intellectual property rights, the faster the technology licensee can learn and imitate the technology of multinational enterprises, and even set up new enterprises to compete with multinational enterprises (Yang and Maskus, 2001).

\section{HORIZONTAL FDI AND VERTICAL FDI}

In addition, FDI can be divided into horizontal FDI and vertical FDI according to motivation. Horizontal FDI refers to the commodity produced by a multinational enterprise in the host country is as the same quality as the parent company, and the product is mainly used for local sales. Vertical FDI, also known as trade-oriented FDI, is motivated by cheap labor and using local natural resources. A rough indicator of differentiation is the destination of the final product: products from affiliate of vertical FDI are used for export, while local sales in foreign markets are more likely to be a symbol of horizontal FDI (Ebghaei and Akkoyunlu, 2018). The level of FDI in mutual investment between developed countries has always 
been the mainstream of international FDI, and similar per capita income and factor endowments make the demand preferences of developed countries similarly, knowledge assets can be invested in branches in different regions withal loss-making, and multinational enterprises have the need to further expand production and take advantage of economies of scale and knowledge assets can be nearly lossless combined into different areas of the branch. All these factors can satisfy the demand of multinational enterprises that they need to further expand production and take advantage of economies of scale. Vertical FDI is designed to capture local cheap production factors, focusing primarily on labor-intensive and resource-intensive sectors rather than technology-intensive and R\&D sectors (Herman, Chisholm and Leavell, 2005). In the case of Developing countries, China, according to the documents from Industry Consulting Expert in China, where horizontal FDI is the amount of $\$ 360$ billion used by affiliates for local sales, and vertical FDI which is also the affiliate selling, is $\$ 338$ billion, and the number of horizontal FDI is roughly the same as vertical FDI, thus showing that vertical FDI accounts for a significant share of developing countries. The mainstream of foreign investment in developing countries comes from vertical FDI in developed countries, and the intellectual capital of the parent company can be further improved in different locations to meet the needs of local consumers and then put into production. Moreover, developing countries can be divided into low-tech and medium-tech due to their different levels of technology. When the product technology level of developing countries is low and vertical FDI is heavy, strengthening intellectual property protection will attract more vertical FDI. Since strengthen intellectual property protection will reduce the barriers set up by transnational corporations which avoid the cost of imitation and maintain the investment motivation of transnational corporations. Thus, if developing countries strengthen the protection of intellectual property, it will increase the ability of attracting FDI(Smith, 2001).

\section{CONCLUSION}

With the development of economy and the improvement of technological level, the proportion of FDI in developing countries will gradually rise, and effective intellectual property protection will lead to the monopoly of multinational enterprises in developing countries with weak imitation ability and medium technological level. Developing countries with low technological level should strengthen intellectual property protection to attract FDI and they should develop and choose the appropriate intellectual property protection method which can match their own level of technology. In the future work, the case study of the variation tendency of FDI from Japan and South Korea for China in few decade years will be presented.

\section{References}

[1] Smith, P. J. (2001). How do foreign patent rights affect U.S exports, affiliate sales, and licenses? Journal of International Economics, 55(2), 411-439. doi:10.1016/s0022-1996(01)000861

[2] Yang, G., \& Maskus, K. E. (2001). Intellectual property rights, licensing, and innovation in an endogenous product-cycle model. Journal of International Economics, 53(1), 169-187. doi:10.1016/s0022-1996(00)00062-3

[3] Hitt, M. A., Ahlstrom, D., Dacin, M. T., Levitas, E., \& Svobodina, L. (2004). The institutional effects on strategic alliance partner selection in transition economies: China vs. russia. Organization Science (Providence, R.I.), 15(2), 173-185. doi:10.1287/orsc. 1030.0045

[4] Herman, M., Chisholm, D., \& Leavell, H. 2005, "FDI and the Effects on Society" Journal of International Business Research, vol. 4, no. 1, pp. 1544-0222.

[5] Luo, Y., \& Tung, R. L. (2007). International expansion of emerging market enterprises: A springboard perspective. Journal of International Business Studies, 38(4), 481-498. doi:10.1057/palgrave.jibs.8400275

[6] Witt, M. A., \& Lewin, A. Y. (2007). Outward foreign direct investment as escape response to home country institutional constraints. Journal of International Business Studies, 38(4), 579-594. doi:10.1057/palgrave.jibs.8400285

[7] Ghosh, S. (2008). Decoding and recoding natural monopoly, deregulation, and intellectual property. University of Illinois Law Review, 2008(4), 1125.

[8] Hargreaves, I. (2011). Digital opportunity: a review of intellectual property and growth: an independent report.

[9] SÁIZ, P., \& CASTRO, R. (2017). Foreign direct investment and intellectual property rights: International intangible assets in Spain over the long term. Enterprise \& Society, 18(4), 846-892. doi:10.1017/eso.2016.92

[10] Ebghaei, F. \& Akkoyunlu Wigley, A. 2018, "The Role of Exports in the Transmission of Horizontal and Vertical Spillovers of Foreign Direct Investment: The Case of Turkish Manufacturing Industry: EXPORTS AND FDI SPILLOVERS", The Developing Economies, vol. 56, no. 1, pp. 35-50.

[11] Ezell, S., \& Cory, N. (2019). The Way Forward for Intellectual Property Internationally. Information Technology and Innovation Foundation. 